\title{
The way of life of the Brazilian pampas: \\ an ethnography of the Campeiros and their animals
}

\section{Flávia Maria Silva Rieth}

Graduate Program in Anthropology, Department of Anthropology and Archaeology, Universidade Federal de Pelotas, Pelotas/RS, Brazil.

\section{Daniel Vaz Lima}

Graduate Program in Anthropology, Department of Anthropology and Archaeology, Universidade Federal de Pelotas, Pelotas/RS, Brazil.

\section{Marilia Floor Kosby}

Graduate Program in Social Anthropology, Department of Anthropology,

Universidade Federal do Rio Grande do Sul, Porto Alegre/RS, Brazil.

\begin{abstract}
In line with the preservation policy on ethnic and cultural diversity of Brazil, the survey of the National Inventory of Cultural References (INRC) - Lidas Campeiras in the Bagé Region sought to inventory the livestock in the Brazilian pampa as a cultural reference. The experience of the research focused on the relationship of culture and nature, specifically the relationship between humans and animals, considered by the dwellers of the Pampa to influence directly the way of life that they lead. The campeiro (pampas person) way of life cannot be conceived without taking into account the oxen, horses and dogs. The paper also the notion of patrimony, taking into account aspects of relatedness, materiality and resonance (Gonçalves 2004).
\end{abstract}

Keywords: Cultural heritage; livestock; pampas way of life; human and non-human relationship.

\section{modo de vida campeiro no pampa brasileiro: Etnografia das lidas com animais}

\section{Resumo}

Em consonância com a política de preservação da diversidade étnica e cultural do Brasil, a pesquisa do Inventário Nacional de Referências Culturais (INRC) - Lidas Campeiras na Região de Bagé, buscou-se produzir conhecimento com intuito de inventariar a pecuária do pampa brasileiro como referência cultural. A experiência da pesquisa privilegiando a relação cultura/natureza, mais especificamente a relação entre humanos e animais. A relação entre humanos e não humanos, desde o início dos trabalhos do inventário, foram enfatizados pelos interlocutores como referências que influenciam diretamente a forma de vida que levam. O modo de ser campeiro não pode ser concebido sem levar em consideração os bois, os cavalos e os cachorros. Atenta-se também para o sentido que a noção de patrimônio assume considerando os aspectos da relacionalidade, materialidade e ressonância (Gonçalves 2005).

Palavras-chave: Patrimônio cultural; pecuária; modo de vida campeiro; relação humanos e não humanos. 


\title{
The way of life of the Brazilian pampas: an ethnography of the Campeiros and their animals
}

\author{
Flávia Maria Silva Rieth \\ Daniel Vaz Lima \\ Marilia Floor Kosby
}

\section{Introduction - Opening the gates for the ethnographic field}

Wearing cowhide boots, bombachas (breeches - baggy pants with loops around the ankles), a leather belt, a knife with a bone handle, a shirt, scarf and hat, the interlocutor known as Minga Blanco, a rural landowner, pampa person and horse tamer in the municipality of Aceguá, located in the pampa of Rio Grande do Sul, talks with anthropologists. Far away we observe two pampa cowboys unsaddling horses after a morning of cattle grazing activities in the field. Minga tells us that when we think of the "gaúcho", we should consider "three pillars": the human, horse and the ox. Three beings whose close relationship centralizes and constitutes a way of life that was historically built implicated in the pampa environment - that is, according to Tim Ingold (2014), affecting and being affected by this environment, in a mutual construction (and deconstruction). The context of this conversation is inserted within an ethnographic work on pampa field work, activities that make up cattle farming in the pampas, a research field whose gates were opened in the work by the "National Inventory of Cultural References - INRC - lidas campeiras (1st Phase)".

The inventory research originated from a demand from the City Hall of Bagé/RS to the IPHAN (Institute of National Historical and Artistic Heritage) and accepted by UFPel (Federal University of Pelotas), through the undergraduate course in Anthropology. The Inventory was conducted from 2010 to 2013, including the training activities of the interdisciplinary team and consultants; delimitation of the research site and surroundings; literature review about cattle farming in Rio Grande do Sul; establishment of a network of interlocutors; execution of the field work with the ethnographic record of production, re-production and trade of bovine, ovine and equine herds that shape the pampas field work; constitution of the document archives by filling the Contacts, Sites and Places forms, Bibliographical Survey, Crafts and Ways of Making, Celebrations, Artifacts and Archives, Sound and Audiovisual Records and the Identification Cards of Inventoried Cultural Goods that make up the INRC Report - Lidas Campeiras in the Bagé Region. The use of this methodology for recording intangible goods of the IPHAN/Ministry of Culture aims to record the bibliographic and ethnographic data on relationships between humans, animals, objects and landscape involved in livestock production in the Brazilian pampas environment, describing the crafts and ways of doing that constitute it. This methodology describes what people do, how they do it, what they do with it and where they do it (Rieth et al. 2013).

The INRC is a methodology developed to document cultural goods through the collection of information about these goods within a historical process and also through ethnographic description,

1 A term here understood as the social being who knows the crafts of livestock management in the pampas. The term gaucho here will not be treated in its homeland designation, that is, as referring only to those individuals of the Brazilian state of Rio Grande do Sul, neither will the meaning of pampas be limited to geographic and biological boundaries, but will also be referred as the agency of relationships established between landscapes, people, animals, crafts and utensils, in creating the "pampas person" way of life (and its construction, abandonment and perpetuation).

2 This research was funded IPHAN. The first phase covers the years 2010-2013. The team of INRC - Lidas campeiras in the region of Bagé/RS consists of the researchers: Flávia Maria Silva Rieth (Coordinator), Marília Floôr Kosby, Liza Bilhalva Martins da Silva, Pablo Dobke, Marta Bonow, Daniel Vaz Lima, Cláudia Turra Magni (Visual Anthropology Consultant), Fernando Camargo (History Consultant), Erika Collischonn (Geography Consultant), Beatriz Freire e Marcus Benedetti (IPHAN). 
apprehending the meanings attributed to them by collectives (Freire 2005), registering them as a cultural reference i.e., in the sense given by Cecilia Fonseca (2006: 89) directing the gaze at the "representations that constitute an 'identity' of the region for its inhabitants and that refer to the landscape, the buildings and objects, the 'practice' and 'knowledge', beliefs, habits, etc. Continuing, the author writes: "When identifying certain elements as particularly significant, social groups operate a resemantization of these elements, relating them to a collective representation that each member of the group somehow identifies with" (Fonseca 2006: 89).

The production of knowledge on cultural goods consists, with reference to the notion of Roy Wagner (2010), of an "invention" of people's way of life from the anthropologist's experience in the context. Through his or her own universe of meanings, the ethnographer who works for the State observes and learns the culture of the "other", building an intelligible and "comprehensive representation" (Wagner 2010: 36), thus enabling the funding and guidance of actions and policies to support these cultural goods (Freire 2005). In this sense, when adopting the methodology of an institution directly linked to the State, we build a "comprehensive representation" in accordance with the notions of culture common among members of the state community. As observed by Wagner (2010) such an invention requires a communication based on shared conventions - through symbolic elements - to make sense. Thus, we observed that in the survey, description and documentation of cultural references, artifacts, places and their transformations, as well as the relationship between humans and animals, are taken into consideration, that is, they are agents that influence the construction of the context. Through this design the researchers at INRC realized that the meeting of these actors constitutes the pampas way of being, intertwining work with the way of life

Answering to the need to classify and safeguard intangible goods, commissions were created by the Ministry of Culture in 2000 in order to propose ways of protecting the collective memory of social groups (Intangible Heritage 2006), with the definition of intangible heritage established by UNESCO in 2003, defined as:

(...) The practices, representations, expressions, knowledge and techniques - together with the instruments, objects, artifacts and places thereby associated - that communities, groups and, in some cases, individuals recognize as part of their cultural heritage. This intangible cultural heritage, transmitted from generation to generation, is constantly recreated by communities and groups due to their environment, their interaction with nature and their history, creating a sense of identity and continuity, thus helping to promote respect for cultural diversity and human creativity (Freire 2005: 16).

In this sense, the term "safeguard" can be understood as measures aimed at guaranteeing the viability of intangible cultural heritage, such as the identification, documentation, preservation and promotion of this heritage in its various aspects. This intangible heritage founded on tradition is presented as intangible as well as totally dynamic, since it reveals a constant changes in its forms of expression. Thinking of cultures as heritage, as Gonçalves (2005) suggests, draws attention to the idea of communication between past and present, the cosmos and society, the individual and the social group, and between history, memory and experience, considering, therefore, the dimensions of resonance, materiality and subjectivity.

Resonance refers us to the meanings of facts beyond conscious and deliberate activity of individuals or groups, addressing the acknowledgement of the specifics of such identification. The emphasis on materiality speaks to the anthropological concept of culture in order to dissociate the tangible and intangible aspects of cultural heritage. On the other hand, these facts are not only symbols that are exterior to the individual. The dimension of heritage is also constitutive of the subjects themselves.

The invention of the pampa culture radicalizes the perspective of the poet Eron Vaz Mattos, another interlocutor of INRC - Lidas campeiras, who considers that the strongest bond between the gaúcho and 
pampas way of life is his deep familiarity with other animals, which constitutes his "understanding of the ground he walks on".

The gaúchos in this research are people who experience or have experienced the work carried out in the industry of extensive livestock farming, producing, maintaining and breeding ovine, equine and bovine herds in the southern tip of South America - a reality that merges the political and geographical boundaries between the state of Rio Grande do Sul and neighboring countries Argentina and Uruguay (Leal 1989; 1992a; 1992b; 1997; Rieth et al. 2011). They are also skilled in the crafts involved in livestock management. When they sell their knowledge as a workforce to others they are called peões campeiros (pampas cowboys).

Among the many activities that can be included in what is known as "pampas field work" are the crafts of the esquiladores (who shear the sheep), tamers, drovers, changueros (who perform different field activities in sporadic occasions), alambradores (who build fences), posteiros (residents that guard the extremities of large estates), care takers, foremen, cowboys, guasqueiros (who make artifacts and utensils in leather), among others, who live or have lived practicing work related to livestock farming ${ }^{3}$. Although certain workers are specialized in one or more of these crafts, a single (and multiple) agent, the campeiro (pampas person), is familiar with and and able to perform each of the crafts that make up the pampa work/life.

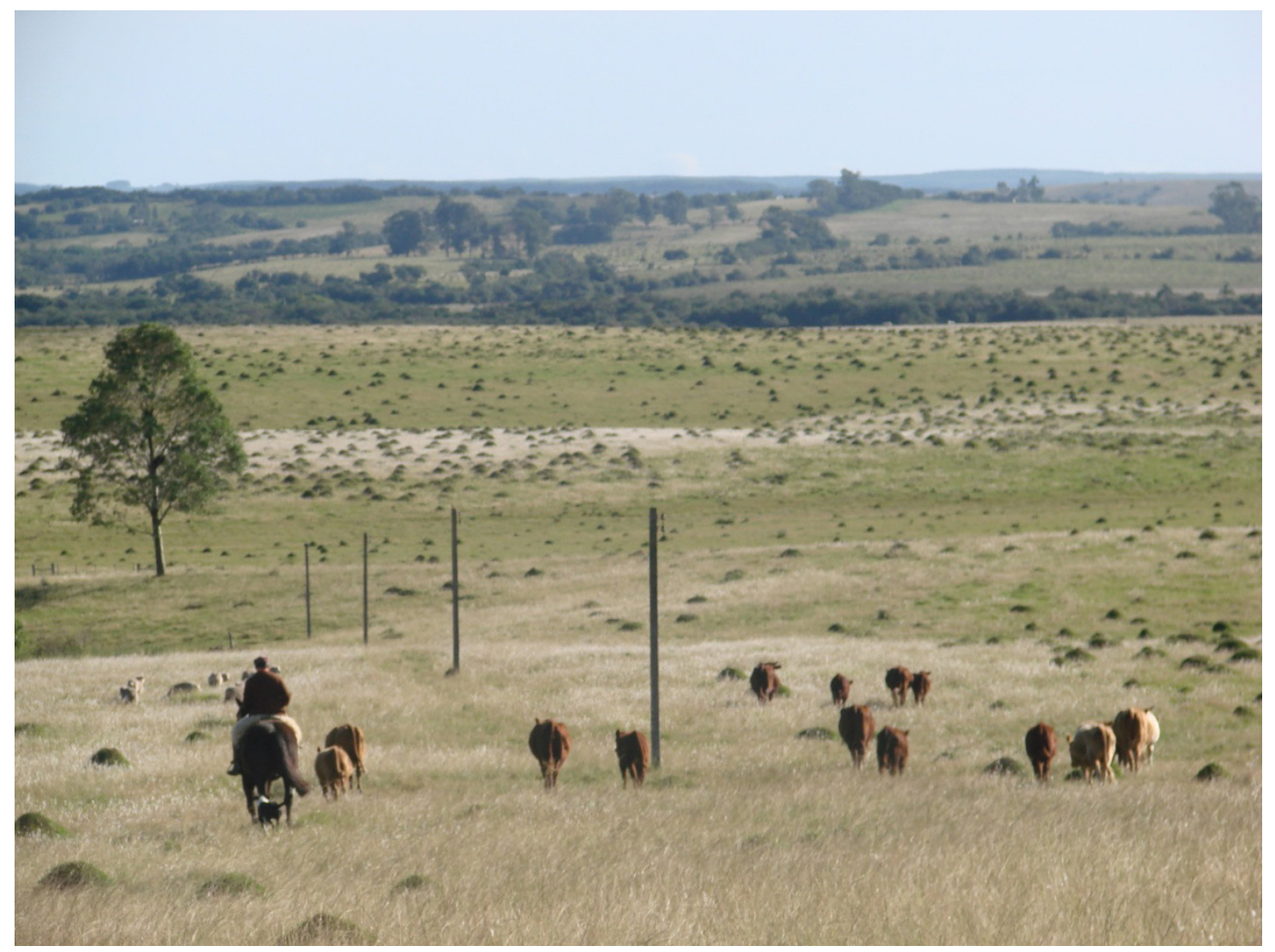

Working with bovine cattle, extensive grazing. Photograph by Marília Floôr Kosby. INRC - Lidas Campeiras in the Bagé Region.

3 According to reports by farmers, the ones who did this work were "the negroes." On the other hand - in an expression that embraces African descent and mestizos with these indigenous - cowboys and cowboys claim that "the bosses didn't like white people doing this job" that was heavy, dangerous and total. Although focused on the past, such statements deal with the ancestors of current pampas people that this study refers to, since such knowledge is generally transmitted from generation to generation. 


\section{Paths and meshes forming the pampas cultural area}

The site of INRC - lidas campeiras is the region of Bagé located in the core area of the Pampa. The suitability of the region for the livestock activity derives from the natural grasslands and from the history of the city as a route of passage and trade between the province and the Platine countries, that led to the establishment of a cultural area (Leal 1997). Ondina Fachel Leal discusses the academic and socio-anthropological establishment of the "South" as a territory of meanings of a specific social reality, a system of values and of a certain social area. For Leal, "the limits of this ethnographed and ethnographable cultural area often called the 'South', in a strategic rhetorical imprecision, do not coincide with the political boundaries of the state of Rio Grande do Sul or even the Brazilian nation.”

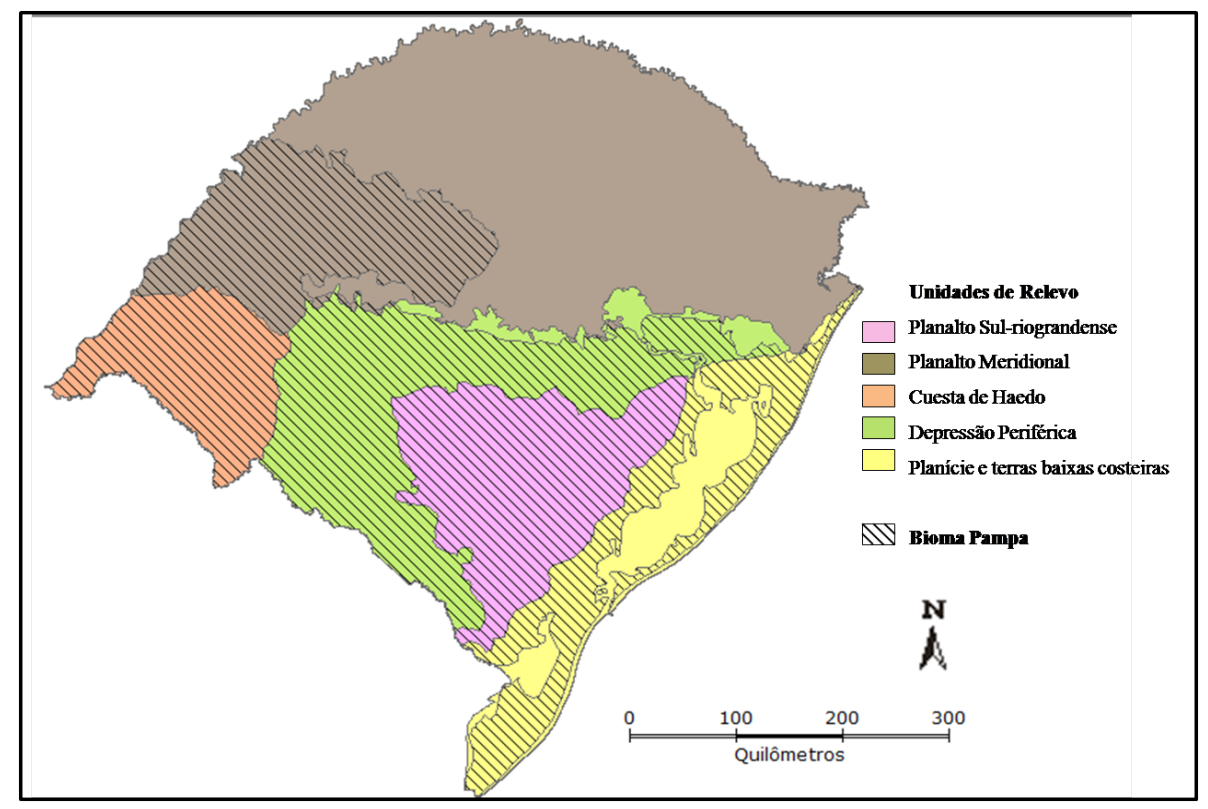

Map elaborated by Prof. Dr. Erika Collischonn (Laboratory of Applied Geography ICH/UFPel). Records of INRC - Lidas Campeiras in the Bagé Region.

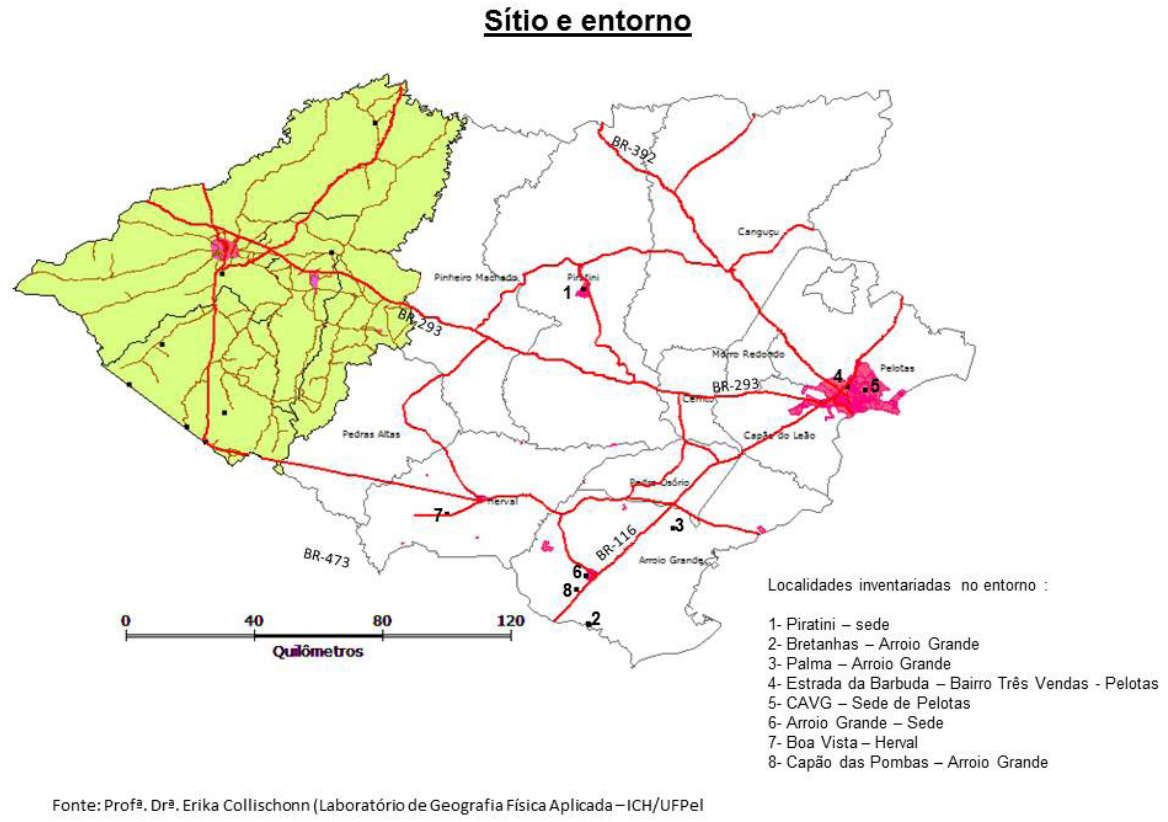

Source: Records of INRC - Lidas Campeiras in the Bagé Region 


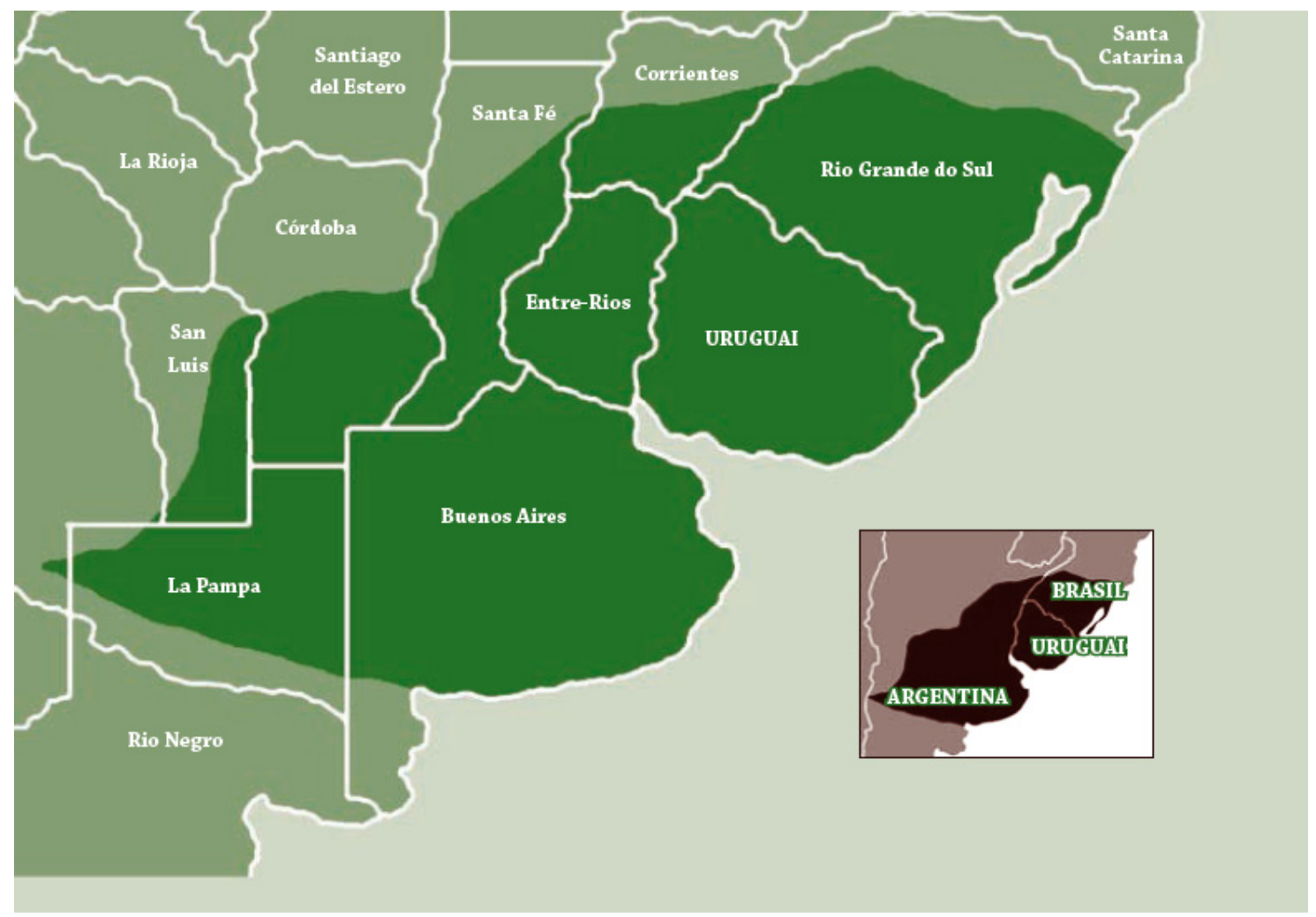

Source: http://biomadospampas.blogspot.com.br/2013/og/localizacao.html (Access: August 22nd, 2016)

For a long time Bagé has been notable for its tradition in the cattle industry, supported by the vast expanse of the region's characteristic fields - the pampas - and the proximity to the neighboring country Uruguay, noted livestock producer, which was of great value to the introduction of purebreds to the bovine farming system, not only in the region, but also throughout the state and the country. Before being domesticated by Mission ranches, the cattle was at first hunted - the so-called high tide of wild cattle - by people wandering over the southern steppes, who were mainly interested in its leather which was valued as a currency for trading in the La Plata River; another important factor at the time was the informal trade with the Banda Oriental, the popular contraband which moved hundreds of heads of cattle from one side to the other, a practice adopted until mid-twentieth century. For Porto Alegre historian settled for many years in Bagé, Claudio Lemieszek, the connection of Bagé to livestock farming is strongly linked to this process of a route of passage for troops and trade with the Platine countries, but mainly to the vastness and good condition of its prairies.

In addition to cattle, the Crioulo horse ${ }^{4}$ and sheep breeding for the region are also of great importance. Their genetic improvement originated a few decades after bovine improvement. Sheep supply the domestic demand for meat on the property, and the annual sale of their wool helped to cover the expenses of property maintenance. With the advent of synthetic wool, sheep farming decreased significantly, supplying meat to specific niches of the market and wool for the production of handmade wool artifacts.

The Bagé region is considered one of the largest horse farming areas in the country, comprising in total 56 horse farms specialized in the breeding and improvement of the Crioulo horse and Thoroughbred breeds. Throughout the $2 \mathrm{o}^{\text {th }}$ century the Bagé region has been the locus not only the genetic improvement of these horses, but also investment in improving ranches, transforming the old farms of extensive farming in pillars of industrial-livestock activity for intensive farming. 
Although we focused our research on the INRC site in the Bagé region, we interviewed pampas people in adjacent and diverse areas such as Hulha Negra, Aceguá, Arroio Grande, Pelotas, Piratini, Herval, Morro Redondo. We therefore included people from the area of natural fields, the Campanha region (plains), and municipalities located in the region of Alto Camaquã/Serra do Sudeste (plateau) and the coastal plain.

In this sense the ethnography by Eric Barreto (2015) conducted in two distinct areas, the Serra do Sudeste and the Campanha region is an important counterpoint. The objective of his research was to investigate the relationship forged between humans and their herding dogs. Both areas have in common the use of dogs, but differences resulting from two main aspects were observed, land setting and geographical context. The municipality of Piratini has a peculiar landscape in the southern half. Located in the Serra do Sudeste, it has a large number of small and medium properties, differing from the large estates predominant in the Campanha region. However, it does not contain an array of small farms as the neighboring municipality of Canguçu. Family livestock farming is the reality of almost all interlocutors of this research. This means a greater need of the dog as a working element, since these farming tasks are performed by a smaller work force than in large farms. The latter, although having currently few cowboys compared to past decades, do not usually delegate tasks to the family of the land owners. In Piratini and Morro Redondo, however, in most cases, the labor agents are the owners themselves and their families, eventually relying on one or two employees. In addition, there is a large amount of native vegetation and landforms, contrasting with the broad grasslands of gentle undulations that become predominant in the Candiota municipality to the west. As a result, one of the challenges in cattle management is removing it from the vegetation, often thick and where horses do not pass. In this case the dog's assistance is invaluable and essential.

In Pedras Altas and Bagé, with landscapes varying from plains covered with grass with some clumps of eucalyptus or narrow riparian forests, and between "dirty" fields (covered by shrub species) and a large number of stones, the reality was a bit different. Besides this geographical difference, the predominance of large properties in the areas we visited leads to different modes of cattle management. In the area of larger estates mainly the salaried employees carry out the work in the fields. Dogs that drive the cattle are a constant presence. When an animal strays, dogs quickly lead it back to the desired location, thereby preventing the horses from getting tired. Not tiring the horse is a constant concern, especially during the summer. In these places, during the research, the workers always conducted their tasks on horseback. In the Serra do Sudeste region we observed activities on horseback and on foot. In many properties of Piratini, the sheep stay close to the house without the need to saddle a horse to reach them. In some of them, just a voice command causes the dogs to seek the sheep.

Even within the municipality of Bagé there are differences. Known for its flat fields and with little vegetation, it also has rugged and forest covered areas near the Camaquã River. On this region we received the following account from a pampas cowboy:

There in Palmas you're nobody without a dog. The cows get caught up in the bush and there's no way of getting them out, a horse won't go in, only a dog. There's an acquaintance of mine who has like ten dogs, he goes out on horseback, but the dogs do all the work. There are a lot of kids (young goats) in those ravines [steep terrains with many stones]. A new cowboy there has to spend some time learning, not everyone gets used to it. One time that acquaintance of mine went to work there, he spent ten days and couldn't stand it, he left. He was an open field, big farm cowboy. He was a good pampas person, but those who work in open fields don't work in Palmas, too many ravines and gorges, people don't like it.

The initial idea of an area originally cut by the paths of the troops, today by roads where such paths existed, appears as an important fact which perpetuates the dynamics of farming/trading of herds of cattle, 
sheep and horses. These paths also lead to neighboring countries of Uruguay and Argentina. In this sense, we look to the flows and networks considering the pampa as a mesh of strings, in allusion to the guasqueiro craft - making leather artifacts - momentarily woven by a mobility of human and non-human elements. In this sense Liza Martins da Silva, when discussing the pampas people in the city, highlights the importance of the relationships between men and their families, animals and artifacts that support the memory: "Thus, the circularity of human and non-human elements comprising this culture surpasses the horizon line of the pampas fields" (Silva 2014: 93). Likewise, Daniel Vaz Lima (2015) talks about the integration of these elements perceived by the concept of Tim Ingold's "mesh", which refers to the intertwining of the trajectories of human animals, non-human animals and artifacts that meet, intertwine, and create different combinations. In Vaz Lima's ethnography on the relationship between humans and horses, he observed that the conversation of the interlocutors revolved around horse stories (and also humans) who have passed through their lives, in which their paths crossed and left marks on the body of those who tame - horse tamers -, as well as marks on their feelings with good and bad memories. For the tamer the relationship with each horse transforms their being and when the animal is sold or delivered to the owner after it is tamed, that is, when it follows its path, the tamer keeps track of the path that the horse he taught continues to build. Different people, from different places and taking different paths have their sociability built by and with animals that also come from different places and are diverse.

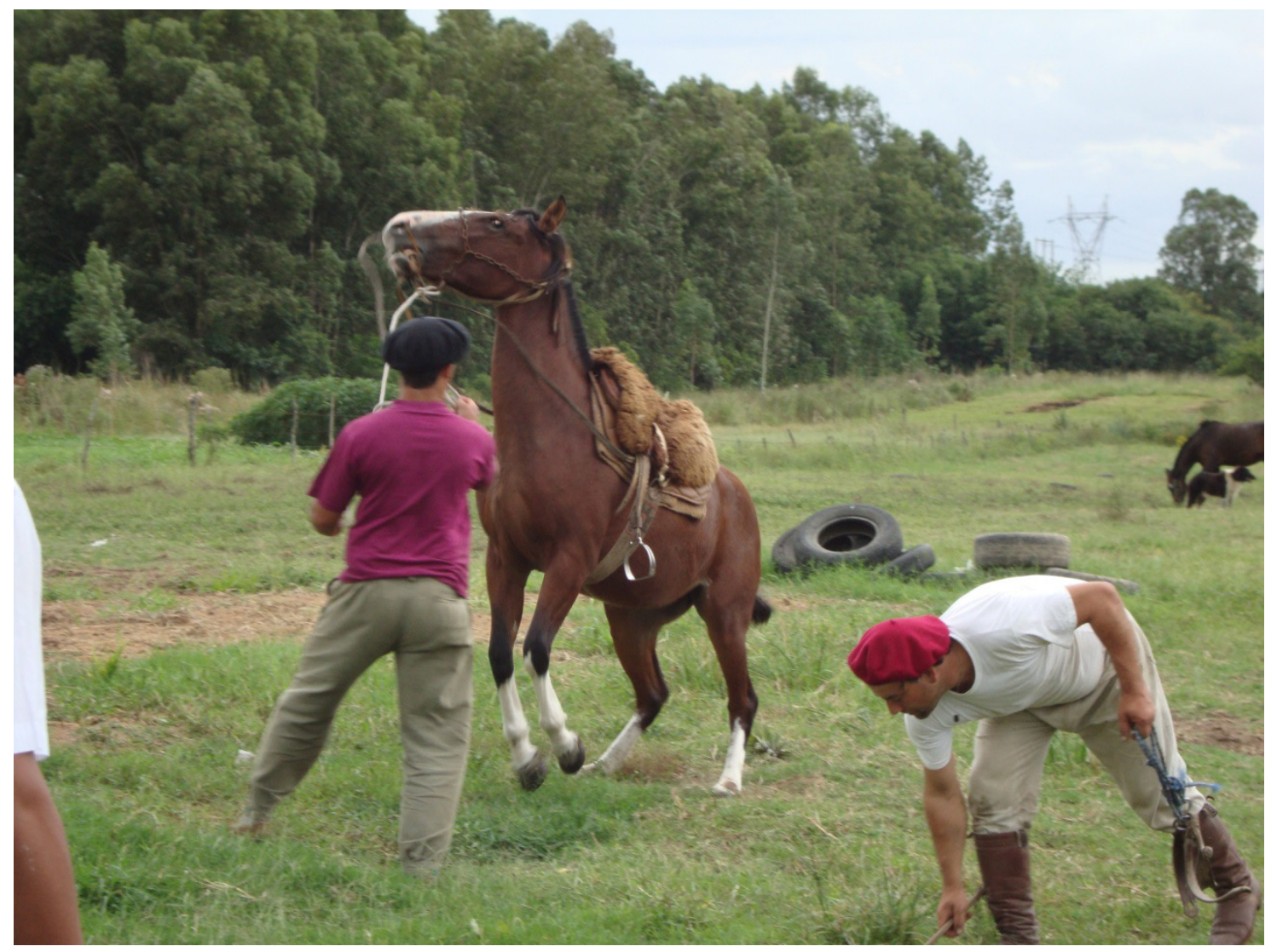

Working with horses: taming. Photograph from interlocutors' personal records. INRC - Lidas Campeiras in the Bagé Region. 
The artifacts that act in the world are also considered in the same sense, not only being perceived by what they represent to the communities, but also in the sense that they organize and constitute social life. The taming artifacts are made, in most cases, by the tamers themselves, who dedicate their "time off from work" to building their trançado (whips woven from leather strips). From the relationship established with the artifact in its making, the tamer has the confidence that it will not break during the moments of taming in which it will be used, as observed in this account: "Sometimes there was a bagual [horse still in the taming process] kinda nasty and I would lasso it, my lasso [which the tamer makes] has always been strong. I would put it around its neck and tie it to a "palanque"s and let him pull at it. "(Mr. Nelson, tamer who resides in Bagél RS). Thus these are human and non-human paths which cross and interweave each other, transforming the actors and their trajectories (Ingold 2012).

\section{Livestock in the pampas within a historical process}

The first major change that shifted the prey or game status of wild cattle to their breeding was the fencing of farms in mid-nineteenth century, initially with vegetation and stones, afterwards with metal wires intercalated with wooden pikes and stone fence posts, the so called wire fences (Moreira 1999). The same development that made the horse an indispensable tool to round up cattle - and the possibility of existence and survival for nomadic hunters - when improved, creates barriers. The mobility that the horse gives the Indian is related to the modernization of the systematization of livestock production. The use of the horse for plowing by indigenous people such as the Charruas and Minuanos was experienced ambiguously, being at the crossroads between the freedom of horseback riding for long distances and the stagnation of having to work in the farms. Herding on horseback is associated with livestock and wire fences, which made groups of Indians more sedentary and almost led to the full extinction of entire societies, due to frontier wars in which the military company was formed mainly by the Indians, who sometimes defended their own territories, and at others fought in national armies. At the same time that they had the means for moving far, the introduction of horses also brought new challenges.

The possibility of valuing the beef, with the advent of the charqueadas (beef jerky) and then refrigerators also changed the relationship with animals - both with regards to the production, as well as the transportation, trade and slaughter. Some farms began only to fatten calves, others maintained the full cycle of production and trade of animals, while others switched back and forth between the two systems. There are ranches where grazing is extensive and there are those who adopt the Voisin system of rotational grazing, the main difference being that "in this case it's the ox that follows the man, not the man who runs after the ox" and horses are rarely used ${ }^{6}$, and there are those who mix the two models.

5 Tree $\log 3 \mathrm{~m}$ high, with $1.5 \mathrm{~m}$ being buried in the ground.

6 The greatest difficulty pointed out by the farmers who try to adopt the Voisin system relates to the difficulty of finding labor-work for this type of herding, mainly because most of the cowboys cannot adapt to working without the lasso and the horse, without requiring violent cattle domination. 


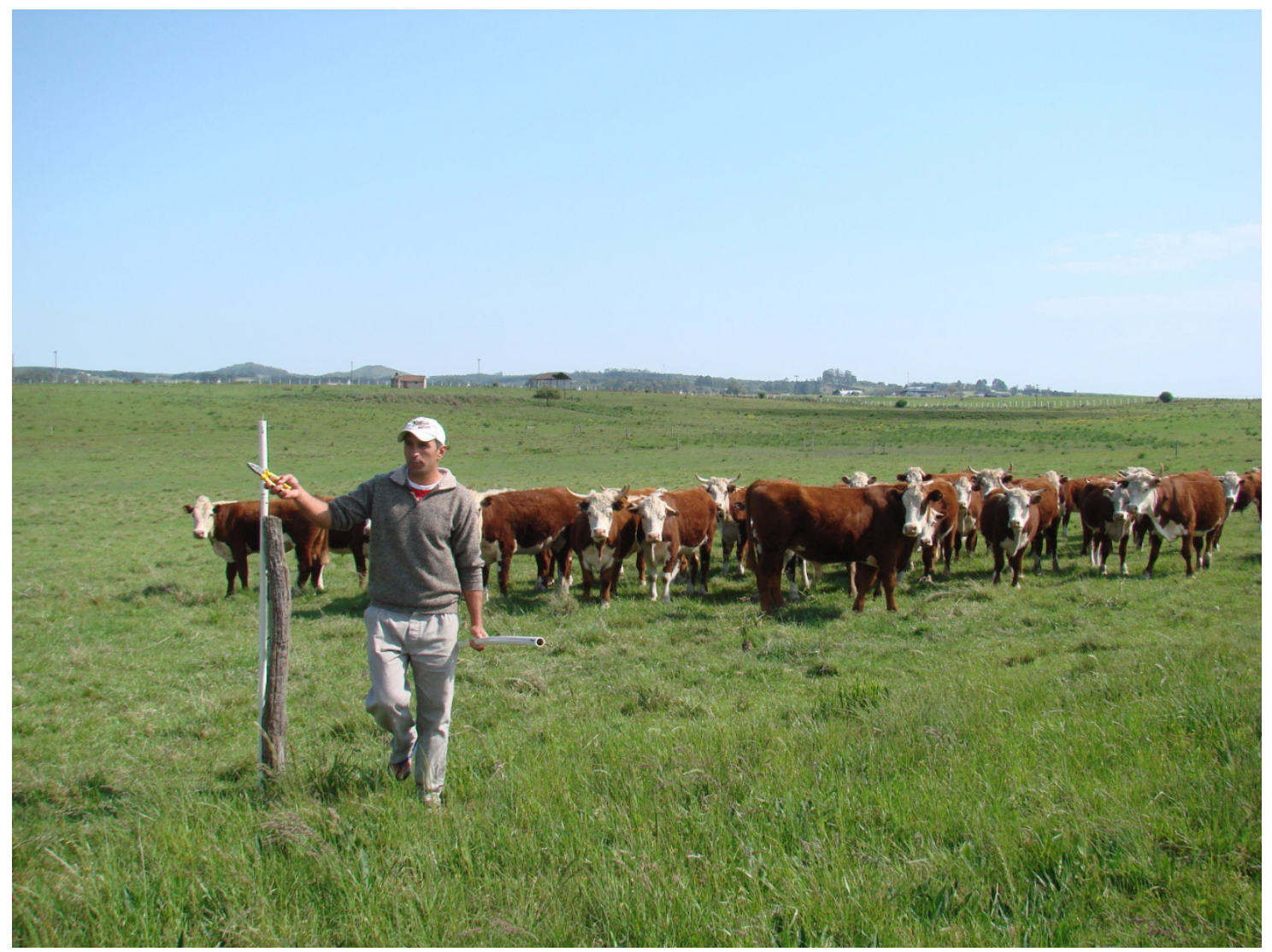

Voisin Grazing. Photograph by Marília Floôr Kosby. INRC - Lidas Campeiras in the Bagé Region.

Waking up before the sun rises a and having to break the frost with the sole of your bare foot, knocking down calves with your own body (since the lasso might fracture the animal), facing the risk of dying against the fury of a bull, participating in the same environment as venomous animals and beasts, facing storms in the middle of the open field to save the calves of a herd, taming bronc horses, the loneliness, the distance, are some aspects identified as responsible for the fact that work in the pampas is "very rough" - which, however, is not enough to represent a negative power since, on the contrary, the control of these situations imposed by the forces of wild nature, (incorporated, of course, by the capitalist exploitation of its workforce), has a constructive agency on the subjects. Although described as arduous, dangerous, unhealthy, this way of life seems to bring in these same hardships the ontological attributes necessary for the construction of these men as people, the maintenance of their existence.

The increasing rationalization and bureaucratization of pampas field work (Cesar 1978), which tamed animals and $\mathrm{men}^{7}$, was directly linked to the transformation of these men from nomadism to sedentarism or migration. The cowboys, posteiros, the foremen, the caseiros (farm sitters) show signs of sedentarization as farm employees even though still in the fields; however it is immanent to the tasks of the esquiladores, alambradores, changueros, herders and tamers the power of not having a stable employer, of working for contracts in the field. Both categories, however, base their ruin on the migration to the city, regretting having to leave the work and their life in the fields.

\footnotetext{
7 As for the pampas field work as a form of socialization of those who somehow cause disorder, it is interesting to know the history of the educational institution Agrotechnical Complex Visconde da Graça, located in Pelotas/RS, covering an area equivalent to 200 hectares within the urban perimeter of the city. Founded in the early 1920s, the Agricultural Employers' Grace Visconde aimed to "qualify free hand labor to work in agriculture and remove from the urban centers the so-called underprivileged of luck, the poor orphans and those marginalized that hinder to the successful development of the centers. " (Vicente 2010: 60). In this sense the school institution was ultimately responsible for the socialization and reproduction of familiar character standards such as the imposition of limits, rules and schedules of those who for legal reasons were under the custody of the school institution (Silva, Pereira \& Vergara 2011).
} 


\section{Experiencing the campeiro work:}

\section{The relationship between humans and non-humans in the pampas}

Richard Sennett (2013) presents reflections on how to understand the craftsmanship within contemporary social relations. The central proposal is to discuss the distinction between the two forms of work developed by Hannah Arendt, in which on one side there is the usual manual work of "animal laborens" where people do not know what they do, and on the other side, there is artisanal activity as work that develops creativity and is the central concept of "homo faber," the human creator of himself. With the transformation in the work place in industrial societies whose social relations are governed by the capitalist mode of production, as craftsmanship incorporates dimensions of capitalist productive processes endangering the activity itself and the workers who are ae transformed from "homo faber" to "animal laborens". Sennet says: "People can learn about themselves through the things they make, material culture is important." (Sennett 2013: 18). All skills, including the abstract, begin as bodily practices of knowledge acquired by hand, by touch and movement. Therefore, technical understanding is training done by the force of imagination that directs and guides bodily ability.

It is noted that the policy of preserving Brazilian cultural heritage is part of a broader process of debate and actions by UNESCO (United Nations Educational, Scientific and Cultural Organisation) in order to preserve and safeguard local knowledge and ways of making, in face of, in the concept of this institution, the advance of globalization whose characteristics are economic interdependence and the intensification of exchanges which could accelerate the disappearance of cultural expressions impoverishing their diversity (Lévi-Strauss 2006: 80). In this sense, the concept that guides the patrimonialization policy is to preserve the knowledge and ways of doing as craftsmanship that in the advance of globalization and the changing world of work in industrial societies could disappear.

Numerous crafts constitute and shape the maintenance of the pampa livestock production. The "pampa field activities" are composed by the following crafts: the shearing of sheep, taming horses, droving, house work (home and daily maintenance of the rural property), herding, making wire fences which are called aramados, and the craft of the guasqueiro (making artifacts and utensils in leather). As we pointed out earlier, these crafts are part of the knowledge of the "pampas person" who is able to execute a little bit of each. The apprentice of a pampas person learns with the others by doing, that is, by engaging in different ways in these "multiple contexts" (Lave 2015) as "changing participants" (ibdem, 2015: 42) moving through the settings (crafts) that influence and shape the learning of this field activity as a whole.

The artisanal way of the life/field work of the pampas person can be understood through the concept of "craftsmanship" (Sennett 2013) which means a high level training whose expansion is built through the relationship between problem solving and detection. The craftsmanship is the incorporation of a conversion process of the information and practices into tacit knowledge (Ibdem, 2013, p. 62). In this sense, the behavior is implicitly related to body education (Mauss 2003), for example, the apprentice becomes a tamer when he learns to "ride a horse", which means when the bodily behavior while mounting is perfected. Therefore, the craftsman refers to a "cultivation of a particular life style," not being an automated procedure but a "cultural issue" (Sennett 2013: 19). The tamer engages in a practical way with his activity as an art, that is, a work focused on the pursuit of quality. The way in which they learn comes from the experience acquired through engaging with the artifacts, with the animals and the environment (Lima 2015). In this sense, craftsmanship, beyond training body movements that expand capabilities, is the result of an interaction between humans and animals and is a learning experience from the encounter with the "other."

The relationship between humans and animals, from the beginning of the inventory, was emphasized by the interlocutors as references that directly influence their way of life. The pampas person way of being 
cannot be conceived without taking into account the oxen, horses and dogs. Nonhumans permeate the topics of conversation and practices of the interlocutors who experience or experienced activities involving livestock in the pampas. Animals accompanied these moments of conversation: The dog lying at the foot of the researchers and interlocutors, the interviews amidst the horses in the spaces in which they are tamed, walking in the field along the interlocutors between the sheep and tame cows that stay close to the house. When analyzed through the established relations it is possible to realize that the animals build and are built as agents that influence this way of life. Sentences in which the speaker says, "if one day I leave the horses it will be very hard for me" (Neco, tamer who lives in Aceguá/RS) and phrases like: "I've always liked to live among horses. That there's a passion, and each one chooses his own" (Sergio, tamer who lives in Pelotas/RS).

The way of life is a construction of knowledge through the experience of interaction with the "other", human and nonhuman. As Tim Ingold has pointed out, the fact of being in the world and being involved with other entities that constitute the environment develops a "skill" that is the knowledge embodied in the modus operandi of the human animal body (and also the non-human animal) through practice and training, "under the guidance of already accomplished practitioners, in an environment characterised by its own textures and topography, and littered with the products of previous human activity. "(Ingold 2010: 16). In this sense, one generation will contribute to the other, through the activities that create environmental contexts where these successors will develop their own skills. "Education of attention" is the learning that takes place through "copying", a mixture of imitation and improvisation:

The novice watches, feels or listens to the movements of the expert, and seeks - through repeated trials - to bring his own bodily movements into line with those of his attention so as to achieve the kind of rhythmic adjustment of perception and action that lies at the heart of fluent performance. (Ingold 2010: 21).

Each participant of an environment acts as if "weaving a thread" and their trajectories, understood as "lines of becoming" of humans and non-humans, create combinations when meeting. The environment is thus a "huge entanglement of lines" (Ingold 2012: 39) that meet and mix in various combinations in a constant process of transformation. The entanglements of these trajectories constitute the environment that surrounds them and converts these lines of becoming into the limits within which life is contained.

The pampas cowboy has to know the ox's language. By observing its body movement and bawl, the pampas cowboy has to know how to act. When he is beside the oxen in a mangueira - corral - the pampas cowboy knows which animal is tame and which one might attack him. The ox that "walks with its head upright" is the most restless and if the cowboy is distracted, it might attack him. Therefore "you can never show you're afraid of the animal", because if you do, "even the tame ones might trample you." Furthermore, different breeds have distinct personalities. The ox of the Zebu breed does not like shouting and dogs and is quite suspicious. If it sees something strange, it will try to flee and seek refuge. The ox of the Devon breed is less suspicious and will try to escape only if the cowboy goes in its direction. The use of violence is established by commercial rules: you cannot hit the animal with sticks and whips because it damages the flesh and when it is slaughtered this injured part will be deducted from the amount paid in cash. In addition, violence without justification is condemned, considering that this action should be only in response to an attack. 


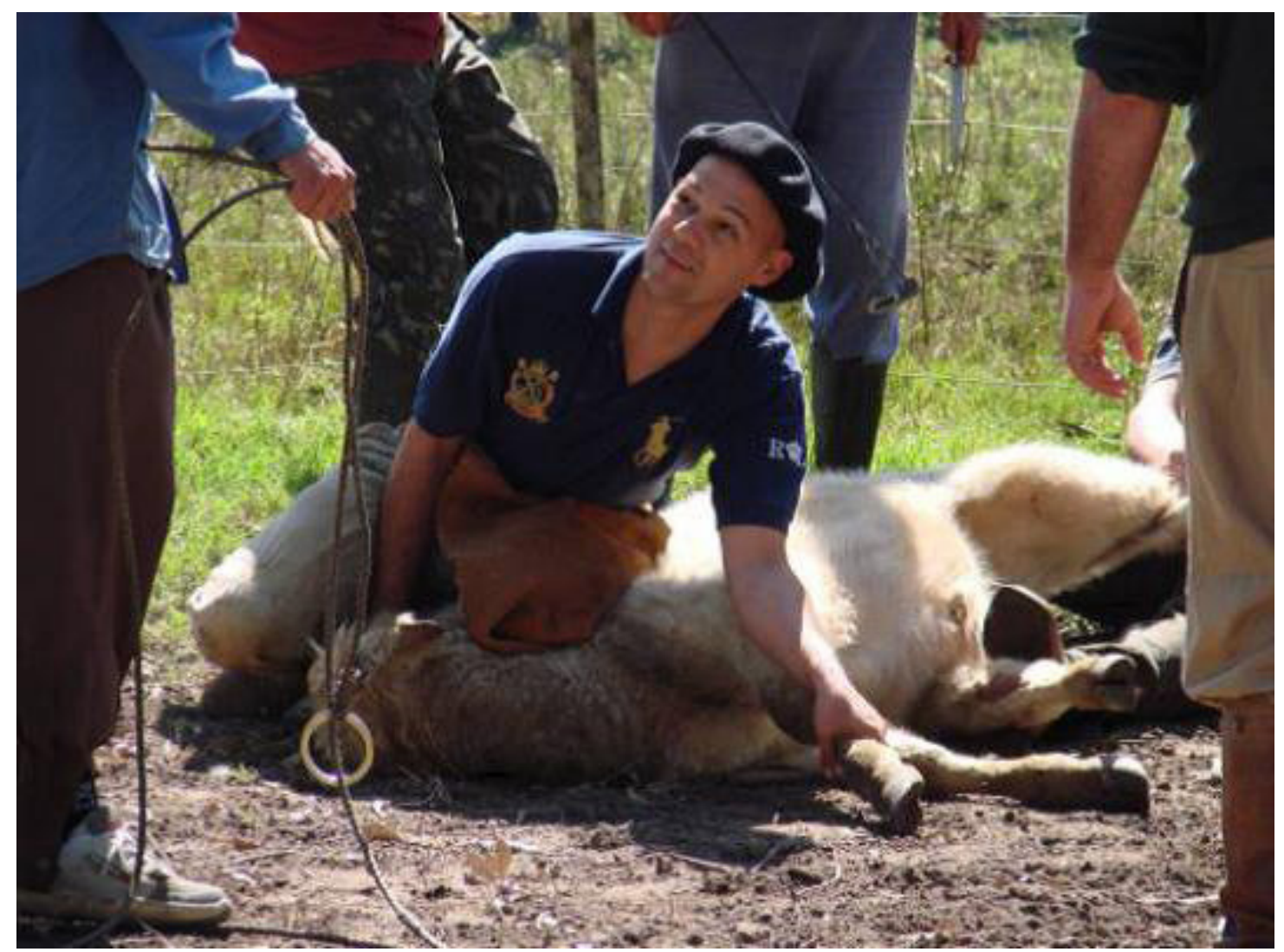

Working with cattle, extensive grazing. Photograph by Marília Floôr Kosby. INRC - Lidas Campeiras in the Bagé Region.

Oxen and sheep are the animals with the most distant relationship with humans. They spend a few days in the field and at any time are sold. As such, they are treated collectively, although eventually some cattle such as dairy cows receive names and special care regarding ration and pasture, as well as a lamb or calf whose mother died and is fed milk from a bottle, they are incorporated in the environment of the pampa people and around the house - the so-called "guaxos" (animals raised without parents). In such cases, to dispose of the animal is something sensitive and they are often sold so they won't have to be slaughtered on the property.

Moreover, when an animal with a close relationship to some pampa person is sacrificed, its leather is used to manufacture a lasso which is a rope made by the guasqueiro from the entanglement of thin strips of leather, called tentos. The characteristic of the ox sacrificed is transmitted to the lasso, that is, if the bovine animal was a "brave bull", the lasso will be strong. The pampa person will feel safe using the lasso made by him or by another guasqueiro, according to the characteristics of the steer whose leather was used as raw material. The boots, belts and knife handles are, in most cases, made with material from bovine and equine animals. The pampa person maintains the bond with the animal through the artifact. So, by observing the artifacts, we see them as a set of intertwined happenings (Ingold 2010). The lasso, for example, made of cow leather that is tanned, made by the hands of guasqueiros who engage in its manufacture, suffers the action of time and therefore we find it lying on the ground, because it will dry up if hung on the wall, each strip is wet with saliva, the best way to take care of it is to rub "green meat" (fresh meat that has not yet been processed) and manure still hot out of the cow after it is sacrificed.

While the relationship between pampa people with oxen and sheep is distant, the relationship with horses and dogs is very close, as can be seen in the description of the routine of a farm located in the municipality of Aceguá in the micro-region of the Campanha of the state of Rio Grande do Sul, 
characterized by extensive cattle farming: chores begin at 6 a.m. when the sun begins to "peek" over the horizon, illuminating the green carpet that stretches over the bent fields. The dairy cows stand by the gate of the potreiro near the houses, which is a small area where the dairy cows and horses that are working in grazing activities are left. They wait for the pampas cowboy, responsible for domestic activities like slaughtering the sheep to be eaten on the farm's property, milking the cows, among others. Cows provide milk and in return gain ration. There has to be this reciprocity in order for the cows to allow the "milk to go down", otherwise they hide and the pampa cowboy cannot milk them because the milk does not come out of the teats. Meanwhile, the other pampas cowboys are preparing to start the field work. The day's task is to "run the field", i.e. to cover, by horse, the area where the cattle is. In this activity they analyze whether any cattle broke through the wire fence and crossed to another field, if there are any cattle "apesteada" (suffering some illness) or with ticks (boophilus microplus). According to their situation the cattle are brought in to be treated in the "mangueira" which is a corral made of stone, wood or surrounded by wires meant to secure the animals being managed.

After drinking the chimarrão, yerba mate (illex paraguariensis) placed inside a container in which is hot water is poured and then drank through a tube called a bomba, and eat the roasted organs of a capão (sheep up to 1.5 years), the pampa cowboys are getting ready to begin the activities of the field work. A pampas cowboy gathers the work horses, i.e. those who will be ridden by the pampas people to work with the cattle. These horses spend the night in the potreiro near the houses and in the cold seasons when the pastures are weak and with few nutrients, they are given ration to gains enough energy to work. Each horse works for two days and then rests in the field and for another two days. The horses are brought to the corral which is attached to the shed in which they keep the saddles and the riding equipment. Small artifacts hang on nails along the wall while larger ones such as the saddles and sheepskin (skin and wool extracted from sheep that are placed over the saddle) on easels. In the corral a pampas cowboy ties a rope to a moirão (fence post) and organizes the horses by stretching a rope and making them rest their chests against it. There are ten horses to be chosen by each four pampas people. The horses are paired up or, as the pampas people say, "in position ". According to the interlocutors, this is done in order to organize the horses and facilitate the work of the pampas people, since when they are dispersed they often do not allow the cowboy to get close enough and grab them. In some cases, the horse does not like the cowboy that is going to grab it and resists being captured. The cowboys also have their preferences and these interactions are built through this encounter of personalities. Keeping the horses in position means organizing the herd so the pampas people can choose. The choice of the horse is also in line with the field work of the day, matching the task the cowboy will perform with the horse's ability to perform such a task. These horses have gone through a process of taming, learning how to execute herding ranch work. The first processes of taming teach the horse how to "interact" with the pampas person through the artifacts, while the learning of the field work is practiced in the field (Lima 2015).

In pastoral activities the skills of humans and horses are complemented by those of the dogs. Pampas people, horses and dogs establish a close knit relationship, forming a team, and the action of one is complemented by the action of the others. This organization seeks to hold and drive the cattle. In each movement of the troops, certain techniques and movements are triggered. The learning by the dogs that perform work activities is also done by a process of incorporating skills established by the practice and experiences of work. Young dogs, through observation and imitation, learn with the adults before taking an effective part in the tasks (Barreto 2015).

"Humans, dogs, horses and cattle are in a constant state of attention ones of the others. Pampas people, horses and dogs pay attention to the movement of the herd. The oxen are attentive to the movements of the dogs and horses. The cows with calves are aware of dogs advancing on them occasionally. The handling of 
the cattle requires some care with certain groups of animals like the "untamed" cattle which are rebellious animals and cows with small calves, since they can attack at any moment of distraction. These groups of animals also control the movement of the dogs and the pampas people on horses, being always aware and watching each other (Süssekind 2014). But the tame cattle are those the pampas people drive to make the herd move since they are afraid of horses and dogs and follow their movement. When an ox rebels, the pampas person frees the rein, which is a rope made of leather connecting his hand to the bit. This movement, along with the body leaning forward, communicates to the horse to race, making it start a rapid movement after the ox, surrounding the animal until finding it. The dog's task is to fetch the oxen which take refuge in the bush. Yapping around the animal and biting its heels make it look for refuge within the herd, forcing it out of the woods. The skills of the horses and dogs are emphasized by the pampa people. A horse or dog considered a "pampas animal" is one who knows what to do in a given action or movement of an ox or herd. If an ox tries to escape a horse that has developed field work skills it will adopt a posture of trying to attack the escape. The pampas person needs to be aware and align the movement of his body to the one of the animal's. The same can be said about the dog that knows how to drive and follow the movement of herds, always driving the cattle from behind and not from up front, which would make the herd retreat and also knowing to bite only at the ox's heels.

Thus, we experience the context of a way of life in which humans and other animals experience a game of gazes and strengths, experiencing encounters that leave marks and knowledge. It turns out that such crafts and their experts hare a way of life that has as an engine of its description/ invention ${ }^{8}$ its own ruin - seen here not as an ending but as a set of transformations that the livestock world suffers since its early signs of initiation in the southernmost portion of Brazil and its bordering (Pereira et al. 2012). In this sense, there are the different ways of managing the herds, in which the rotational grazing method Voisin stands out in the region, for introducing management without the use of chemical implements as acaricides, alternating occupation of pasture and animals, altering the relationship of humans and animals in extensive work. In the work employed it is "the ox that follows the man, not the man who runs after the ox" and activities are performed without horses and dogs. The daily contact between livestock and the "cowboy on foot" strengthens the relationship between them. According to an interlocutor, a pampas person in the "Conquista farm" in the municipality of Bagé, RS, a farm reference in the implementation of such management, the cattle sees a human in another way, not as predator, but as "a person who is dealing with him every day." This interlocutor, who learned the craft of a pampa person working on the farms, notices that in the Voisan method the cowboy does not "touch the cows", screaming and using dogs and horses, but invites the cattle with the expression "come, $o x$ " while they respond immediately by following the pampa person. Instead of a wire fences an electric fence divides the property into small areas called piquetes. Instead of horses, dogs, spurs and rebenques (a type of small stock whip), there is a "levante", a stick averaging two meters in height which lifts the edge of the electric fence for the animals to pass when they are changing piquetes. The owners of the "Conquista farm" list the difficulties in hiring pampa people to work with the Voisan method. They mentioned these workers' resistance in "working on foot", without horses or dogs or the artifacts that have learned to work with.

These rural workers move between the countryside and the city, between farms and hostelries. They are driven by work, with a certain nomadism, strengthening ties of sociability at horse races, pampas events like rodeos that also bring together humans and nonhumans. Alongside the humans we observed the circulation of animals and objects. The horse and the loose dog (but not abandoned) in the city evoke

8 According to Roy Wagner (2010), culture is an intellectual creation that arises from the encounter of two varieties of the human phenomenon, a relationship that is more real than the things that are related. It is therefore the contrast that makes the notion of culture visible, as it is not something absolute, objective. The other, therefore, is part of a "reality" invented according to your own creativity - which is not a reflection of the anthropologist. 
the living "out there", in freedom. Thus, the denomination of the pampas culture is invented from the interaction of relationships established in the mutual implication of landscapes, men and women, animals, crafts and objects, in the configuration of a "pampas" way of life in its construction, abandonment and perpetuation.

\section{Final considerations}

The purpose of this text was to present the patrimonialization process of knowledge and ways of doing that make up the livestock network in the Brazilian pampas, presenting the researchers' field experience in order to invent, that is, to build a "comprehensive representation" (Wagner 2010) of this way of life for the eyes of the state as well as of society. Investing ethnography in the experience of people and relating them to the broader socio-economic and cultural transformations, we realized that social relations within the pampa livestock context involve the direct influence of the animals. The pampa person's way of being cannot be conceived without taking into account the presence of the cattle, horses and dogs, that pervade conversation and practices of the interlocutors who experience or experienced activities involving livestock in the pampa. Our ethnographic writing sought to plot the elements of this way of life from the description of pastoral activities that are constituted by skills developed from the relationship established between the pampa people with artifacts / objects, with animals and with different pampa environments.

Translated by Luciana de Sant Anna Dall Agnol

Received: 31 December, 2015, Approved: 18 July, 2016

\section{References}

BARRETO, Eric. 2015. "Por dez vacas com cria eu não troco o meu cachorro": as relações entre humanos e cães nas atividades pastoris no pampa brasileiro. Dissertação de Mestrado, Programa de Pós-Graduação em Antropologia da Universidade Federal de Pelotas - Pelotas, RS.

CESAR, Guilhermino. 1978. O Conde de Piratini e a Estância da Música. Porto Alegre: Educs.

FONSECA, Maria Cecilia de Londres. 2006. "Referências culturais: base para novas políticas de patrimônio". In: Patrimônio imaterial: o registro do patrimônio imaterial. Dossiê final das atividades da Comissão e do Grupo de Trabalho do Patrimônio Imaterial. Brasília: Ministério da Cultura/ Instituto do Patrimônio Histórico e Artístico Nacional, 4 ed. pp. 83-98.

FREIRE, Beatriz Muniz. 2005. “O inventário e o registro do Patrimônio Imaterial: Novos instrumentos de preservação". Cadernos do LEPARQ: textos de arqueologia, antropologia e patrimônio, 2(3): 11-20.

GOLDMAN, Márcio. 2005. "Formas do saber e modos do ser: observações sobre multiplicidade e ontologia no candomblé". Religião e Sociedade, 25(2): 102-120.

GONÇALVES, José Reginaldo Santos. 2005. "Ressonância, materialidade e subjetividade: as culturas como patrimônios”. Horizontes Antropológicos, 10(22): 15-36.

INGOLD, Tim. 2010. "Da transmissão de representações à educação da atenção". Educação, 33(1): 6-25.

INGOLD, Tim. 2012. "Trazendo as coisas de volta à vida: emaranhados criativos num mundo de materiais". Horizontes Antropológicos, 18(37): 25-44. 
INGOLD, Tim. 2014. “That's enough about ethnography!” Hau: Journal of Ethnographic Theory, 4(1): 383-395.

LAVE, Jean. 2015. "Aprendizagem com/na prática”. Horizontes Antropológicos, 21(44): 37-47.

LEAL, Ondina Fachel. 1989. The Gaúchos: male culture and identity in the Pampas. Tese de doutorado, University of California - Berkeley, EUA.

LEAL, Ondina Fachel. 1992 a. "Honra, morte e masculinidade na cultura gaúcha”. In: Ari P. Oro; Sérgio A. Teixeira (coords.), Brasil e França: ensaios de antropologia social. Porto Alegre: Ed. Universidade (UFRGS). pp. 141-150.

LEAL, Ondina Fachel. 1992 b. "O Mito da Salamandra do Jarau: a constituição do sujeito masculino na cultura gaúcha”. Revista de Psiquiatria do Rio Grande do Sul,1(14): 8-11.

LEAL, Ondina Fachel. 1997. "Do etnografado ao etnografável: o ‘Sul' como área cultural”. Horizontes Antropológicos, 3(7): 201-214.

LÉVI-STRAUSS, Laurent. 2006. "Patrimônio imaterial e diversidade cultural: o novo decreto para a Proteção dos bens imateriais". In: Patrimônio imaterial: o registro do patrimônio imaterial. Dossiê final das atividades da Comissão e do Grupo de Trabalho do Patrimônio Imaterial. Brasília: Ministério da Cultura/ Instituto do Patrimônio Histórico e Artístico Nacional. 4ª ed. pp. 77-82.

LIMA, Daniel Vaz. 2015. "Cada doma é um livro": a relação entre humanos e cavalos no pampa-sul-rio-grandense. Dissertação de Mestrado, Programa de Pós-Graduação em Antropologia da Universidade Federal de Pelotas - Pelotas, RS.

MAUSS, Marcel. 2003. Sociologia e antropologia. São Paulo: Cosac Naify.

MOREIRA, Igor. 1999. O espaço rio-grandense. São Paulo: João Guizzo Editor.

PATRIMÔNIO IMATERIAL. 2006. O registro do patrimônio imaterial: dossiê final das atividades da Comissão e do Grupo de Trabalho do Patrimônio Imaterial. Brasilia: Ministério da Cultura/ Instituto do Patrimônio Histórico e Artístico Nacional, $4^{\mathrm{a}}$ ed.

PEREIRA, Fabíola M., RIETH, Flávia; KOSBY, Marília. 2012. “Inventário Nacional de Referências Culturais Pecuária, Bagé/RS (1âfase)”. Anais da Reunião Brasileira de Antropologia, GT 05, São Paulo. Ms.

RIETH, Flávia; KOSBY, Marília et al. 2011. "INRC- Bagé/RS: Inventário do Sistema da Pecuária no sul do Rio Grande do Sul". Anais da IX Reunião de Antropologia do Mercosul. GT "Familias, afetos e patrimônio". Curitiba. Ms.

RIETH, Flávia; KOSBY, Marilia; SILVA, Liza Bilhalva da; RODRIGUES, Marta Bonow; DOBKE, Pablo; LIMA, Daniel Vaz. 2013. Inventário Nacional de Referências Culturais: Lidas Campeiras na Região de Bagé, RS (volume 3). 1 a . ed. Arroio Grande: Complexo Criativo Flor de Tuna.

SENNETT, Richard. 2013. $O$ artífice. Rio de Janeiro: Record.

SILVA, Cristiano Lemes; PEREIRA, Fabíola Mattos; VERGARA, Camile. 2011. "Signos, práticas e representações: um estudo antropológico sobre a reprodução da cultura gaúcha em uma escola agrícola de Pelotas/RS”. Anais do XX congresso de Iniciação Científica da Universidade Federal de Pelotas. Pelotas. Ms.

SILVA, Liza Martins Bilhalva da. 2014. Entre lidas: um estudo de masculinidades e trabalho campeiro nas cidades de Bagé e Pelotas/RS. Dissertação de Mestrado, Programa de Pós-Graduação em Antropologia da Universidade Federal de Pelotas -Pelotas, RS.

SUSSEKIND, Felipe. 2014. $O$ rastro da onça: relações entre humanos e animais no Pantanal. Rio de Janeiro: 7 Letras.

VICENTE, Magda de Abreu. 2010. O Patronato Agrícola Visconde da Graça em Pelotas/RS (1923-1934): gênese e práticas educativas. Dissertação de Mestrado, Programa de Pós-Graduação Educação da Universidade Federal de Pelotas - Pelotas, RS.

WAGNER, Roy. 2010. A invenção da cultura. São Paulo: Cosac Naify. 
Flávia Maria Silva Rieth

Graduate Program in Anthropology, Department of Anthropology and Archaeology, Federal Universidade Federal de Pelotas, Pelotas/RS, Brazil.

E-mail: riethuf@uol.com.br

\section{Daniel Vaz Lima}

Graduate Program in Anthropology, Department of Anthropology and Archaeology, Federal Universidade Federal de Pelotas, Pelotas/RS, Brazil.

E-ail:dvlima.vaz@gmail.com

Marilia Floor Kosby

Graduate Program in Social Anthropology, Department of Anthropology,

Universidade Federal do Rio Grande do Sul, Porto Alegre/RS, Brazil.

E-mail: floorkosby@gmail.com 